\title{
When and how? Freshwater mussel recolonization in Lake Orta
}

\author{
Nicoletta RICCARDI,${ }^{*}$ Elsa FROUFE, ${ }^{2}$ Manuel LOPES-LIMA, ${ }^{2,3}$ Claudio MAZZOLI ${ }^{4}$ \\ ${ }^{1}$ National Research Council, Institute of Ecosystem Study, L. Tonolli 50, 28922 Verbania-Pallanza, Italy; ${ }^{2}$ Interdisciplinary Centre of \\ Marine and Environmental Research (CIIMAR/CIMAR), University of Porto, Rua dos Bragas 289, 4050-123 Porto, Portugal; \\ ${ }^{3}$ IUCN/SSC - Mollusc Specialist Group, c/o IUCN, Pembroke St, Cambridge CB2 3QZ, UK; ${ }^{4}$ Department of Geosciences, University \\ of Padua, Via Gradenigo 6, 35131 Padova, Italy \\ *Corresponding author: n.riccardi@ise.cnr.it
}

\begin{abstract}
Thanks to a video posted on a social network, live mussels of Unio elongatulus, have been recorded from Lake Orta (Italy) over one century after the last (and only) report. With its long and well documented history of pollution, Lake Orta offers the opportunity to document the post-extirpation recovery of freshwater unionid mussels. This case evidences that recovery/recolonization is possible despite a high devastation in the past, and permits to evaluate how fast recolonization may occur, in which way, and in what conditions. The answer to the how fast was sought by estimating the age of the larger and seemingly older individuals of the population. To address the in which way we compared the haplotypes of Lake Orta specimens of Unio elongatulus (the only species present) with those of surrounding populations. We concluded that, since Lake Orta lacks a direct connection with the putative source populations, colonizing mussels were almost certainly transported by fish carrying glochidia that were used for lake restocking after liming. Data from the long-term monitoring of water chemistry and sediments have allowed defining what conditions proved to be suitable for survival making possible the start of mussels recovery. But not only water and sediment quality matters for mussels recovery, which was delayed by nearly ten years after the reappearance of fish. This delay reflects the need of the whole trophic chain to be reestablished to allow the survival of the suitable and healthy host-fish populations necessary for mussels reproduction.
\end{abstract}

Key words: Mussel recolonization; Unio elongatulus; molecular analysis; age estimation; population structure.

Received: June 2015. Accepted: October 2015.

\section{INTRODUCTION}

Being nearly sessile, with a long span-life and a complex life-cycle, freshwater mussels (Bivalvia: Unionida) are forcedly so vulnerable to environmental changes that they have been declining for decades (Matteson and Dexter, 1966) and are among the most imperilled aquatic animals worldwide (Lydeard et al., 2004; Strayer, 2008; Haag, 2012). Water pollution and habitat alterations likely prompted the decline of mussels in the early $20^{\text {th }}$ century, and are overwhelmingly indicated as the major causes of mussel extirpation (Downing et al., 2010). Mussels decline whenever the change of environmental conditions goes beyond their ability to adapt. Faced with multiple stressors, mainly of anthropogenic origin such as habitat loss, degradation and fragmentation, mussels have their Achilles' heel in a suite of traits that make them unable to adjust to these changes (Watters, 2000; Hastie et al., 2003; Lydeard et al., 2004, Galbraith et al., 2010). First of all adult mussels have limited displacement ability (Green $e t$ al., 1985; Amyot and Downing, 1997; Waller et al., 1999) that prevents them to escape adverse conditions. Mussel life histories vary widely among and within species but, generally, as all long-lived species, mussels grow slowly, have delayed maturity and most species have a lower fe- cundity than previously believed for the group (Haag, 2013). Since their larvae (glochidia) survivorship is very low $(<<1 \%)$ and recruitment can be highly variable among the years, fecundity has little influence on population growth compared to adult survival (Haag, 2012). If population abundances are severely reduced, a negative density dependence can lead small and scattered populations to collapse, even after the removal of the original causes of decline (Downing et al., 1993). Although adult mussels can withstand short-term environmental perturbations, the life history of most unionoids includes several critical periods, such as sperm release by adult males into the water column, uptake of sperm by siphoning females, fertilization of ova, release of viable glochidia from females, and attachment of glochidia to a suitable host fish (encysted) for transformation to a free-living juvenile mussel (McMahon and Bogan, 2001; Watters, 2007). Water and sediment quality, health of host fish, and food availability, all have the potential to influence survival during each of these life stages and subsequent reproduction and recruitment. Thus, the population dynamics of freshwater mussels are complex, and populations may exhibit negative growth and highly variable recruitment, while adult individuals thrive (Strayer et al., 2004). For these reasons, naturally reproducing unionid populations 
can take decades to recover after severe and prolonged disturbances.

Even though the study of these taxa has increased over the past few decades, their conservation still faces several challenges. Foremost, basic life history, distributional information (Neves, 1993; Strayer, 2006), and their habitat preferences are essential for freshwater mussels' conservation (Jones and Byrne, 2010, 2014) and are lacking for many species. Although many threatening processes have been identified (Downing et al., 2010; Nobles and Zhang, 2011), the possibility of recovery/recolonization after complete extirpation is still an understudied issue. Examples of natural post-extirpation recovery are still too rare to allow us to answer crucial questions, such as whether, how fast, in what conditions and in which way recolonization can take place (Henley and Neves, 1999; Sietman et al., 2001; Crail et al., 2011). In addition, inadequate funding (a nearly universal problem) for long-term monitoring may limit the opportunity to detect the eventual recolonization. Potentially exacerbating this problem is the difficulty to locate freshwater mussels, particularly when rare and small young individuals begin to colonize a new area. This is what seemingly occurred in Lake Orta, that since 1926 underwent a catastrophic industrial pollution event which destroyed the biotic community (Bonacina, 2001, and references therein). Lake restoration by treatment of discharges and liming intervention resulted in a relatively rapid recovery of the pelagic community. Conversely, the post-liming ten-year long monitoring failed to detect any improvement of the benthic community (Nocentini et al., 2001). Whole groups of organisms such as Mollusca were missing (Tesauro et al., 1995; Baudo et al., 2001a; Nocentini et al., 2001) at least until 1998, when the last survey of the benthic littoral community was performed (Bielli and Tesauro, 2001). There are no data from the lake after that date, but the lack of mussels has been taken for granted based on the legacy effects of the accumulated toxics that resulted in long-term effects on populations (Strayer et al., 2004). In addition, a natural recovery of mussels (Neves, 1993) was considered unlikely due to the apparent lack of access to restocking populations (Strayer et al., 2004).

Unexpectedly, the presence of mussels in Lake Orta was revealed by a video posted on a social network in 2012 and delivered to the first author of the present study in November 2014. For its long and well documented history of pollution, Lake Orta offers the opportunity to improve knowledge about the ability of unionid freshwater mussels to recover from ecosystem disturbances.

The importance of such information for conservation and management has stimulated this research that is intended to verify mussels' distribution, extent, population density and size/age structure. Furthermore, genetic analyses have been performed in order to confirm species identification and to identify possible donor populations.

\section{METHODS}

\section{Study area}

With a surface area of $18.5 \mathrm{~km}^{2}$, a maximum depth of $143 \mathrm{~m}$ (mean depth $71 \mathrm{~m}$ ) and a volume of $1.3 \mathrm{~km}^{3}$, Lake Orta is the seventh largest Italian lake by volume (Fig. 1). Located in Northern Italy $\left(45^{\circ} 46^{\prime}-45^{\circ} 52^{\prime} \mathrm{N}\right.$ and $8^{\circ} 23^{\prime}$ $8^{\circ} 26^{\prime} \mathrm{W}$ ) the lake experienced a catastrophic destruction of its biota following pollution caused by the discharge of huge amounts of copper and ammonium sulphate from a rayon factory, established at the southern end of the lake in 1926 (Calderoni et al., 1991). The discharge of ammonium sulphate did not initially result in an increase of inlake ammonium concentration. Instead, biochemical oxidation of $\mathrm{N}-\mathrm{NH}_{4}$ caused nitrate $\left(\mathrm{N}-\mathrm{NO}_{3}\right)$ to accumulate in the lake in the 1950's. Already poorly buffered (total alkalinity ranging between $0.3-0.4 \mathrm{mEq} . \mathrm{L}^{-1}$ ) because of the watershed geology, the lake underwent progressive acidification to values as low as 3.8 in 1985 (Calderoni and Tartari, 2001) along with increasing ionic copper concentration, which exceeded $100 \mu \mathrm{g} . \mathrm{L}^{-1}$ in the 1950's (Corbella et al., 1958). At the beginning of the 1980's a recovery phase began with the installation of a treatment plant at the rayon factory, which substantially reduced copper and ammonia loadings. Water chemistry suddenly improved, but $\mathrm{pH}$ was still very acid and alkaline reserves were absent (Mosello et al., 1986a, 1986b; Bonacina et al., 1988a, 1988b). A liming treatment applied in 19891990 (Calderoni et al., 1991) was immediately effective in raising the $\mathrm{pH}$ (from 3.9 to 6.5), increasing the alkaline reserve, and causing the flocculation and sedimentation of toxicants. This permitted the recovery of the biotic pelagic community (Calderoni and Tartari, 2001; Baudo, 2002), but it also caused further disturbance to the benthic community by transferring water pollutants to the sediments. For instance, the average concentration of copper in the surficial sediments increased from $843 \mathrm{mg} \cdot \mathrm{kg}^{-1}$ (before liming, i.e. 1992) to $997 \mathrm{mg} \cdot \mathrm{kg}^{-1}$ in 1996 (and the maximum values increased from 1978 to $2440 \mathrm{mg} \cdot \mathrm{kg}^{-1}$ ) (Baudo and Beltrami, 2001). Several toxicity tests ran in the years following liming (1992-1998) confirmed that the sediments were contaminated enough to induce either a direct short term mortality or sublethal effects on crustacean species (Rossi and Beltrami, 1998; Beltrami et al., 1999; Barbero et al., 2001; Baudo et al., 2001b; Burton et al., 2001). This likely hindered the re-colonization by most benthic taxa resulting in a benthic community that was both poorly structured and scanty and with a small number of taxa, and whole groups of organisms, such as Mollusca, missing (Tesauro et al., 1995; Baudo et al., 2001a; Nocentini et al., 2001; Bielli and Tesauro, 2001). 


\section{Sampling}

Preliminary qualitative surveys were performed in January and February 2015 to evaluate the presence of mussels along the lake perimeter. Two major difficulties in locating bivalves in large lakes are depth and accessibility to the coastal zone. Given such limitations, we decided to use a two-step approach. The first step was an extensive beach and shallow nearshore survey along the lake perimeter, which took advantage of the flooding event that had occurred in November 2014. We focused on identifying fresh dead and/or live mussels washed up during this event to obtain preliminary information needed to define locations for diving surveys. Banks and shoreline areas were also searched at each site for muskrat feeding stations (shell middens).

The second consisted in diving surveys in some sampling locations which revealed signs of bivalves during the previous step as well as in sites with suitable habitat that were accessible by boat only. During each dive, the lake bottom was visually inspected and searched by sweeping hands across the top of the substrate or probing the substrate to find buried mussels.

Quantitative sampling, performed on January $11^{\text {th }}$ and February $15^{\text {th }}$, was restricted to one area (Fig. 1, $45.763722,8.424895$ ) of approximately $3200 \mathrm{~m}^{2}$ which was found to be colonized. Since visual inspection detected a density gradient with depth, stratified sampling (Strayer and Smith, 2003) was used for quantitative estimates of mussels densities. Firstly, the area was divided into 8 reaches of about $20 \times 20 \mathrm{~m}$ (i.e., $625 \mathrm{~m}^{2}$ ): 4 reaches within high-density depth range (i.e., depth $<2 \mathrm{~m}$ ), and 4 in the low density depth (i.e. depth $<4 \mathrm{~m}$ and depth $>2 \mathrm{~m}$ ). We decided to concentrate maximum efforts on the highdensity stratum where 20 quadrats $\left(0.25 \mathrm{~m}^{2}\right.$ each $)$ were sampled, while other 10 quadrats were sampled in the low-density stratum. Within each reach, sampling units (quadrats) were selected randomly, excavated to a depth of $15 \mathrm{~cm}$ and all mussels were removed; this method did not allow sampling of individuals less than $5 \mathrm{~mm}$ in length. The mean density in the study area was calculated as the mean in each stratum weighed by the size of the stratum (Strayer and Smith, 2003).

On the assumption that the mussels were accidentally introduced with fish restocking, specimens from 13 surrounding locations were also collected for genetic analyses (Tab. 1). Five sites were chosen for their proximity $(<25 \mathrm{Km})$ to Lake Orta (L. Mergozzo, L. Maggiore, L. Monate, L. Comabbio and L. Varese); the other eight sites were chosen randomly within a distance of $150 \mathrm{~km}$ at most from Lake Orta. Documents on fish restocking made by the local authorities are unavailable, but it is likely that
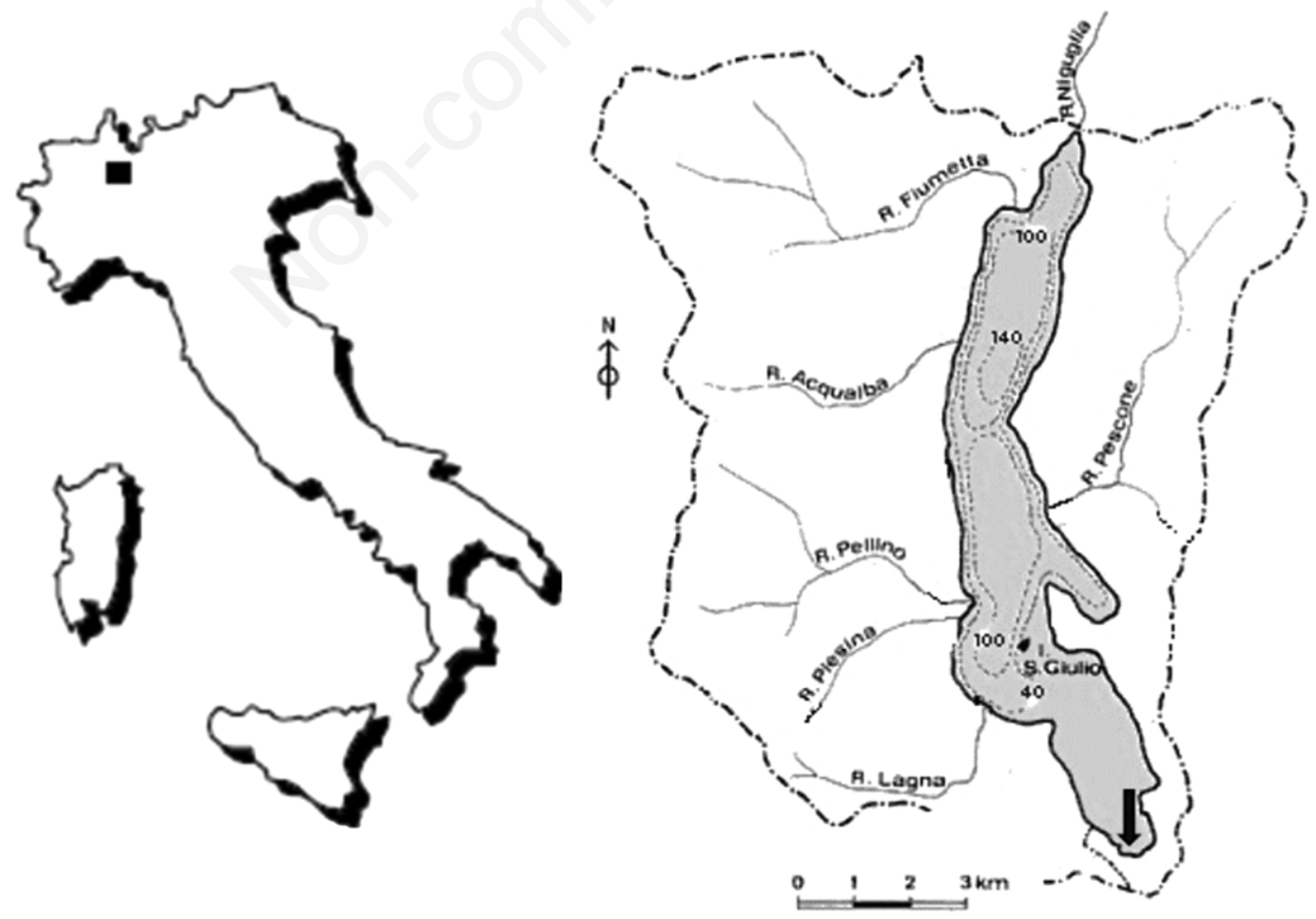

Fig. 1. Hydrographic basin with main tributaries and bathymetry of the Lake Orta. Arrow: sampling area. 
the potentially introduced fish species, now present in Lake Orta, have been collected from the surrounding water bodies.

\section{Samples measurements}

Live mussels were identified to species, counted, and released into the environment, to prevent impoverishment of the population.

To minimize disturbance, we avoided large sampling sizes and prolonged handling of the mussels during the field surveys and only a small number of specimens $(n=11)$ were carried to the laboratory for genetic analyses and age estimation (Haag and Commens-Carson, 2008a, b). Therefore, only 33 specimens were sampled and measured in the field with a digital calliper to the nearest 0.01 $\mathrm{mm}$, defining the following morphometric variables: shell length (L), the maximum antero-posterior dimension of the shell; shell width (W), the maximum left-right dimension with both valves compressed; and umbo height $(\mathrm{H})$, the dorsal-ventral dimension of the shell measured perpendicular to the length measured at the level of the umbo.

\section{Age estimation}

To obtain a more accurate estimate of the age and growth of individuals, we counted annual rings in thin sections of the shells following the recommendations of Haag and Commens-Carson (2008). Only the first two years were recognized using the external rings due to the strong corrosion of the umbonal region in most samples. A thin section of one valve was prepared from each of the 11 sacrificed individuals, and shell rings were studied and used for age estimation. Valves were consolidated by daubing with epoxy resin and cut using a Buehler Isomet 1000 precision saw along a line, starting from the peak of the umbo and crossing perpendicular to the growth lines towards a point slightly posterior of the midpoint of the valve. The flattened cut surface was attached to standard frosted glass slide using epoxy resin, cut and ground to approximately 300 microns using a Buehler PetroThin thin sectioning system, and wet-sanded on 800 and 1200 grit sandpaper. Annual shell rings were recognized under standard petrographic optical microscope, supported by images of the entire

Tab. 1. List of samples examined with respective GenBank accession codes, information about location, coordinates, and haplotypes.

\begin{tabular}{|c|c|c|c|c|c|c|}
\hline Code & Species & Local & Latitude & Longitude & Haplotype & Genbank \\
\hline U004I & U. elongatulus & Po River & 45.149091 & 8.329459 & 7 & KU051599 \\
\hline U008I & U. elongatulus & Mergozzo Lake & 45.948094 & 8.471800 & 7 & KU051600 \\
\hline U022I & U. elongatulus & Mergozzo Lake & 45.948094 & 8.471800 & 4 & KU051601 \\
\hline U039I & U. elongatulus & Torrente Marcova & 45.219297 & 8.450624 & 7 & KU051602 \\
\hline U040I & U. elongatulus & Torrente Marcova & 45.219297 & 8.450624 & 8 & KU051603 \\
\hline U047I & U. elongatulus & Cervo Tributary & 45.438008 & 8.341107 & 2 & KU051604 \\
\hline U058I & U. elongatulus & Lake Viverone & 45.413609 & 8.048871 & 6 & KU051605 \\
\hline U059I & U. elongatulus & Lake Viverone & 45.413609 & 8.048871 & 6 & KU051606 \\
\hline U072I & U. elongatulus & Lake Candia & 45.321260 & 7.913934 & 2 & KU051607 \\
\hline U073I & U. elongatulus & Lake Candia & 45.321260 & 7.913934 & 1 & KU051608 \\
\hline U074I & U. elongatulus & Lake Candia & 45.321260 & 7.913934 & 2 & KU051609 \\
\hline U080I & U. elongatulus & River Adda & 45.742784 & 9.450628 & 2 & KU051610 \\
\hline U081I & U. elongatulus & River Adda & 45.742784 & 9.450628 & 7 & KU051611 \\
\hline U088I & U. elongatulus & Lake Endine & 45.765387 & 9.925804 & 2 & KU051612 \\
\hline U089I & U. elongatulus & Lake Endine & 45.765387 & 9.925804 & 2 & KU051613 \\
\hline U108I & U. elongatulus & Lake Varese & 45.819828 & 8.746780 & 5 & KU051614 \\
\hline U111I & U. elongatulus & Lake Varese & 45.819828 & 8.746780 & 7 & KU051615 \\
\hline U117I & U. elongatulus & Lake Comabbio & 45.769634 & 8.700080 & 7 & KU051616 \\
\hline U118I & U. elongatulus & Lake Comabbio & 45.769634 & 8.700080 & 2 & KU051617 \\
\hline U133I & U. elongatulus & Lake Annone & 45.810234 & 9.358439 & 2 & KU051618 \\
\hline U134I & U. elongatulus & Lake Annone & 45.810234 & 9.358439 & 3 & KU051619 \\
\hline U140I & U. elongatulus & Lake Monate & 45.797097 & 8.668908 & 7 & KU051620 \\
\hline Biv1840 & U. elongatulus & Lake Orta & 45.812808 & 8.388920 & 7 & KU051621 \\
\hline Biv1841 & U. elongatulus & Lake Orta & 45.812808 & 8.388920 & 7 & KU051622 \\
\hline Biv1847 & U. elongatulus & Lake Orta & 45.812808 & 8.388920 & 7 & KU051623 \\
\hline JX046578 & U. elongatulus & Lake Maggiore & 45.929437 & 8.570981 & 7 & JX046578 \\
\hline JX046579 & U. elongatulus & Lake Maggiore & 45.929437 & 8.570981 & 7 & JX046579 \\
\hline JX046580 & U. elongatulus & Lake Maggiore & 45.929437 & 8.570981 & 7 & JX046580 \\
\hline
\end{tabular}


thin section obtained by merging sets of high resolution images. Non-annual rings and, more rarely, disturbance rings were also observed and appear markedly different from annual rings. Annuli are generally broader, continuous from the outer surface towards the umbonal area becoming parallel to the internal surface, and apparently crossing the prismatic layer. Instead, internal annuli apparently end against the prismatic layer, and coalesce within a single ring within the shell. Annual rings were also verified in cathodoluminescence using a CITL CCL 8200 Mk3 chamber on a Nikon Labophot-2 Pol microscope. Cathodoluminescence was also used to analyse the tightly crowded shell rings of older individuals characterized by low growth rates.

To estimate shell length growth, the position of the annual bands were located on the shell surface by juxtaposing the marked thin section with the cut half of the shell and then transferring these marks to the shell surface (Haag and Commens-Carson, 2008). This allowed to measure the shell length directly at each annulus. In older specimens it was possible to measure length only up to age 4 to 8 years because the highly crowded nature of later annuli made them difficult to locate with precision on the shell surface. The size increment corresponding to these remaining growth bands was calculated by scaling the measurements obtained from thin sections for the corresponding years. To estimate age-at-length relationship the size-at-age data were used to calculate the von Bertalanffy growth curves using the software Growth II (Henderson and Seaby, 2006). The inversion of the von Bertalanffy growth equation estimated from the sacrificed specimens was used to predict age from length measurements of the specimens released into the field.

\section{DNA extraction, amplification and sequencing}

For the genetic analyses, small mantle samples were excised in 25 animals from 13 locations (Tab. 1). Whole genomic DNA was extracted from small tissue pieces preserved in 96\% ethanol, using a standard high-salt protocol (Sambrook et al., 1989). A fragment of $\sim 700 \mathrm{bp}$ of $\mathrm{CO} 1$ gene was amplified by PCR using the $\mathrm{LCO} 22 \mathrm{me} 2$ and HCO700dy 2 primers (Walker et al., 2006, 2007). The PCR conditions $(25 \mu \mathrm{L}$ reactions) are described elsewhere (Froufe et al., 2014), with the annealing temperature being done at $50^{\circ} \mathrm{C}$. Amplified DNA templates were purified and sequenced externally by Macrogen, using the same primers.

All three COI sequences of Unio elongatulus available on GenBank (Tab. 1) were downloaded and aligned with those obtained in the present study. To evaluate relationships among the obtained closely related haplotypes, sequences were joined in a statistical parsimony network, constructed under a 95\% criterion using TCS 2.1 (Clement et al., 2000).

\section{RESULTS}

Extensive surveys along lake perimeter failed to detect mussels except for one single location (Fig. 1) corresponding to the area which was primarily affected by industrial discharges of the Bemberg factory since 1926 (Bonacina, 2001; Baudo and Beltrami, 2001). Average population density was 3.9 ind. $\mathrm{m}^{-2}$ with maximum value of 5.4 ind. $\mathrm{m}^{-2}$ at $<2 \mathrm{~m}$ depth ( $1.3 \pm 1.2 \mathrm{ind} /$ quadrat; $\mathrm{N}$ quadrats $=20)$ and a decrease at 2-4 $\mathrm{m}$ depth to 2.4 ind. $\mathrm{m}^{-2}(0.6 \pm 0.4 \mathrm{ind} /$ quadrat; $\mathrm{N}$ quadrats $=10$ ). Since the colonized area surface is about $3200 \mathrm{~m}^{2}$, the mussels' population is estimated to amount to about 12,500 individuals. The largest individuals were $9 \mathrm{~cm}$ in length and 14 years old, while the smallest one was $3 \mathrm{~cm}$ in length and 2 years old. Large individuals $(>7.5 \mathrm{~cm})$ older than 10 years formed $48 \%$ of the population, another $48 \%$ was made up of medium-sized 7-8 years old individuals, but the presence of different size classes and of small-young specimens - though rare - suggested that recruitment was occurring (Fig. 2). Estimates of the von Bertalanffy parameters suggest that individuals were approaching their maximum length $(\mathrm{L} \infty=86.49)$ quite rapidly $\left(\mathrm{K}=0.30\right.$ year $\left.^{-1}\right)$ as is usual for shorter-lived freshwater mussel species (Haag and Rypel, 2010). Most growth occurred within in the first 3-4 years of life, while after the $6^{\text {th }}$ year the growth curve of all specimens flattened, approaching asymptote (Fig. 3). Specimens born before 2004 grew faster than younger ones, as evidenced by comparing the slope of the growth curves calculated over the first six years of life (Student' $t$ test $=3.45 ; \mathrm{P}<0.05$ ).

\section{Molecular analyses}

Both forward and reverse sequences from the 25 specimens were aligned, and no indels and no stop codons were observed, after translating all sequences to amino acids. At the $95 \%$ confidence limit, TCS produced a network shown in Fig. 4. The new sequences (GenBank

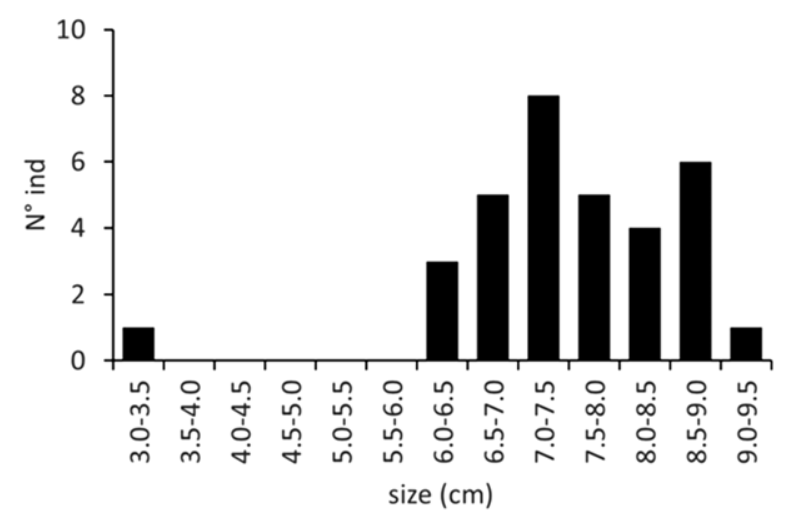

Fig. 2. Size frequency distribution. 
numbers will be provided upon acceptance of the ms) and the previously published ones, correspond to $U$. elongatulus as only a single network was produced. From all the $U$. elongatulus sequences analysed, eight distinct haplotypes were resolved (Tab. 1). All Lake Orta individuals shared the same haplotype (7) which was also present in eight of the other thirteen sites (Tab. 1).

\section{DISCUSSION}

This study reports the first record of live unionid mussels in Lake Orta after more than one century. The last (and at the same time the first) report dates back to the late 1800s, when Pini (1884) described three species of Unionid mussels, Unio cusianus, Anodonta brevirostris and A. palustris (or paludosa). This is the only information available for bivalves from this lake, since, like most other biota, mussels disappeared soon after the onset of pollution in 1926 which destroyed the entire food web from the basis, phytoplankton, to the top, fish (Monti, 1930). Severe acidification and increase of metal concentrations (Bonacina et al., 1986; Bonacina, 2001) prevented their recovery over the following decades, as testified by many studies (Moretti, 1954a, 1954b; Oioli, 1969), which revealed a littoral fauna reduced to a tiny, monotonous community composed of highly adaptable species completely lacking entire groups, including molluscs. Even after the improvement of Lake Orta conditions and the neutralization of $\mathrm{pH}$ values accomplished by liming (1989-1990), studies documenting the progressive recovery of both pelagic and benthic populations (Baudo et al., 2001a; Bielli and Tesauro, 2001; Nocentini et al., 2001) failed to reveal the presence of mussels or any other molluscs. Since mussels are highly sensitive to acidification (Økland and Økland, 1986; Taskinen et al., 2011), ammonia (Augspurger et al., 2003; Wang et al., 2008) and heavy metals (Naimo, 1995; Keller et al., 2006), particularly at the earlier life stages (Wang et al., 2007a, 2007b; Cope et al., 2008; Cleawater et al., 2014), the high sediment toxicity, that did not improved but was rather worsened by liming, likely hindered recolonization. Furthermore, once extirpated from a water body, mussels are not able to recolonize easily, particularly if they lack access to restocking populations (Strayer et al., 2004), due to constraints related to their complex life cycle. Host specificity and host abundance also limits mussels recruitment and, consequently, post-extirpation recovery of naturally reproducing populations. It was just before liming that fish reappeared in Lake Orta, mainly represented by Perca fluviatilis, and some specimens of Squalius cephalus and Lepomis gibbosus (Baudo, 2002) both suitable host species for Unio elongatulus (Castagnolo 1977). The multiple age classes composing the current mussel population suggests the occurrence of recent recruitment, in accordance with the evidence of a complete recovery of the fish littoral community (Volta et al., 2016).

The question now is what are the origins of the unionids observed in Lake Orta? Do they represent introduction or dispersal from neighbouring water bodies or tributaries? Or might they represent a population that is recovering/expanding from few relict survivors that have gone unnoticed in potential refugia after the catastrophic disturbance of Lake Orta? Indeed, in a very small scale the water quality could have been maintained by inflow of underground or surface water. However, data on the composition and abundance of benthos in 1996 do not seem to indicate that the conditions for survival were better in the area currently colonized than in the rest of the littoral zone (Baudo et al., 2001a). In spite of the adaptation of Lake Orta benthos to high metal concentrations (Baudo et al., 2001a), no freshwater mussels were found in the area that is now colonized neither in 1993-1994 (Nocen-
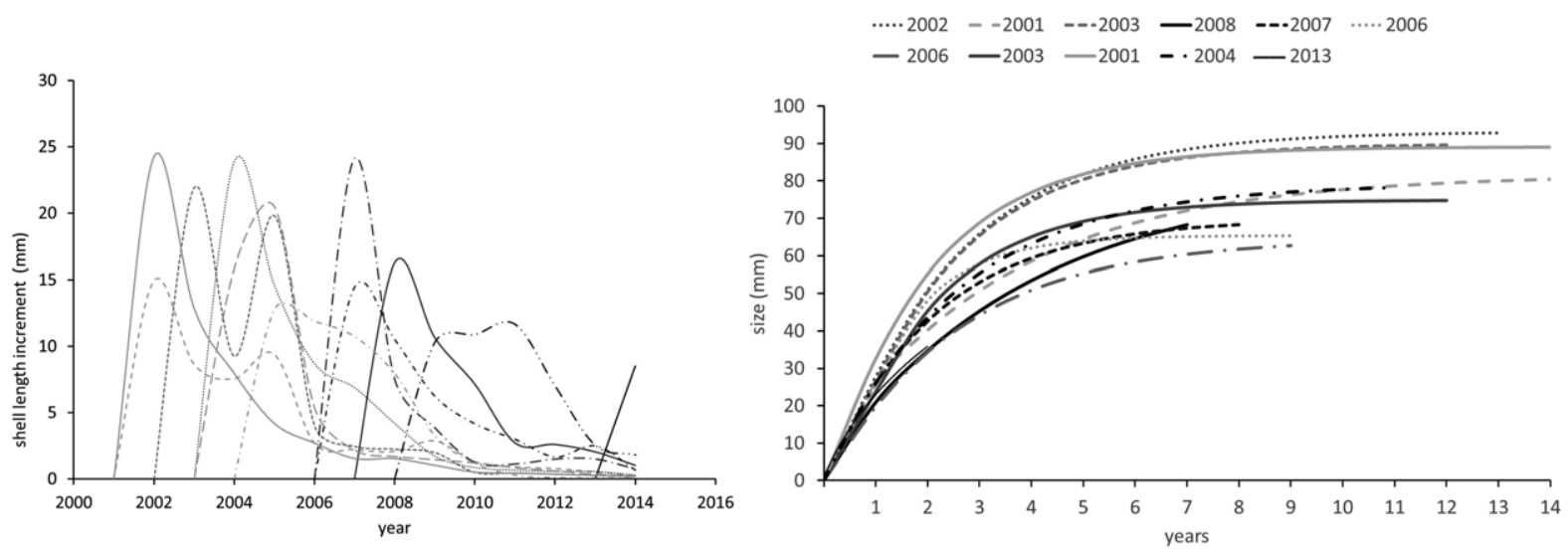

Fig. 3. Annual length increment (left) and individual von Bertalanffy growth curves (right, year of birth specified in legend). 
tini et al., 2001) nor in 1996 (Baudo et al., 2001a) and 1998 (Bielli and Tesauro, 2001). Therefore, the most likely hypothesis, also supported by genetic analysis, is a recolonization from a broodstock in a neighboring population, most probably that of Lake Maggiore or Lake Mergozzo, which are the closest sites with genetically similar populations. Since a direct water connection with putative donor populations is lacking, due to the presence of a dam at the Lake Orta outflow from early 1900's, release of glochidia from fish used for restocking likely occurred. No data on fish restocking could be obtained by local authorities (Provinces), apart from the generic information that this was done repeatedly after the liming.

Since released glochidia larvae are more vulnerable to contaminants than glochidia attached to fish, or juvenile mussels (Taskinen et al., 2011), it seemed very important to try to define what conditions proved to be sufficient for Unio to re-colonize. Searching for an answer about the time of the supposed introduction, we estimated the age of individuals chosen by different size classes. The oldest animals in the population are 14 years old. For species with a relatively short life-span like $U$. elongatulus (Nardi, 1972) the date of introduction of the population cannot be inferred from the age of the oldest individuals. However, based on the maximum age estimation, a deadline can still be established in Lake Orta with mussels appearing no later than 2001. This means that mussels recolonized at least 15 years ago, when the lake was recovering but the sediment toxicity was still high (Baudo et al., 2001b) and $\mathrm{pH}$ acidic (6.8 in the winter, Calderoni and Tartari, 2001). Harsh hydrochemical conditions at colonization time are testified by the degree of erosion and shape of the shell of older mussels. Indeed, these effects have been previously described for mussels from acidic waters (Preston et al., 2010). The increase in the epilimnetic pH to alkaline values during summer (Rogora et al., 2016) likely enabled mussels to grow, while $\mathrm{pH}$ lowering at winter mixing caused shell corrosion.

A difference in growth-rate was observed between older and younger individuals, with the latter growing slowly, contrarily to what we expected. Indeed, if the habitat improves gradually, then older individuals should have deteriorated growth (Dunca et al., 2005), while younger should grow faster, and/or reach highest absolute sizes. We could tentatively interpret the lower growth of the younger specimens with a reduction of the nutrients loads to the lake. The annual phosphorus load from the tributaries decreased from 6-10 $\mathrm{t} \mathrm{P} \mathrm{yr}^{-1}$ before 2004 to values close or below $2 \mathrm{t} \mathrm{P} \mathrm{yr}^{-1}$ in very recent years (Rogora et al., 2016). Though admittedly speculative for the small number of individuals we sacrificed, this hypothesis is matched by the evidence that Unio elongatulus has higher growth rates and larger size in eutrophic than in oligotrophic water bodies (Ravera et al., 2003, 2007). Lake
Orta can be classified as oligotrophic or ultra-oligotrophic, with very low total phosphorus concentrations (Rogora et al., 2016). Under severe nutrient limitation even a single discharge of organic matter can modify the trophic conditions at local scale, and particularly in littoral shallow waters. Whatever the explanation, the variation in growth among specimens of different age do not indicate that earlier habitat conditions were worse than the present situation.

The negative effect of liming on sediment composition was forecasted to delay for decades the recovery of the benthic community (Baudo and Beltrami, 2001), and particularly of the least tolerant components. On the contrary, our observations highlight that mussel occurrence in Lake Orta, although limited in the area surveyed, was already possible only ten years after. An improved water chemistry of pelagic waters, which was proved to be representative also of littoral areas [Cattaneo et al. (2011) characterized the beginning of the colonization (Tab. 2)]: acid-base status of Lake Orta had completely recovered, ammonium levels had lowered, falling in the range of those observed in the other subalpine oligotrophic lakes, while nitrate was still $>1 \mathrm{mg} \mathrm{L}^{-1}$. Present concentrations of $\mathrm{Fe}, \mathrm{Mn}, \mathrm{Al}$ and $\mathrm{Cu}$ in the water column are as low as those of the nearby Lakes Maggiore and Mergozzo (Rogora et al. 2016) while, Ni and Cr, although at low levels, still might pose a threat for biota (Piscia et al., 2016). No data is available on sediment chemistry after 1996 (Baudo and Beltrami, 2001) when the area colonized was highly enriched in $\mathrm{Cu}\left(\sim 2000 \mathrm{mg} \mathrm{kg}^{-1}\right), \mathrm{Cr}\left(\sim 1000 \mathrm{mg} \mathrm{kg}^{-1}\right), \mathrm{Pb}$ $\left(\sim 500 \mathrm{mg} \mathrm{kg}^{-1}\right)$ and $\mathrm{Mn}\left(\sim 1500 \mathrm{mg} \mathrm{kg}^{-1}\right)$ with pore water concentrations of $\mathrm{Cu}$ and $\mathrm{Cr}$ respectively of 0.63 and 0.10

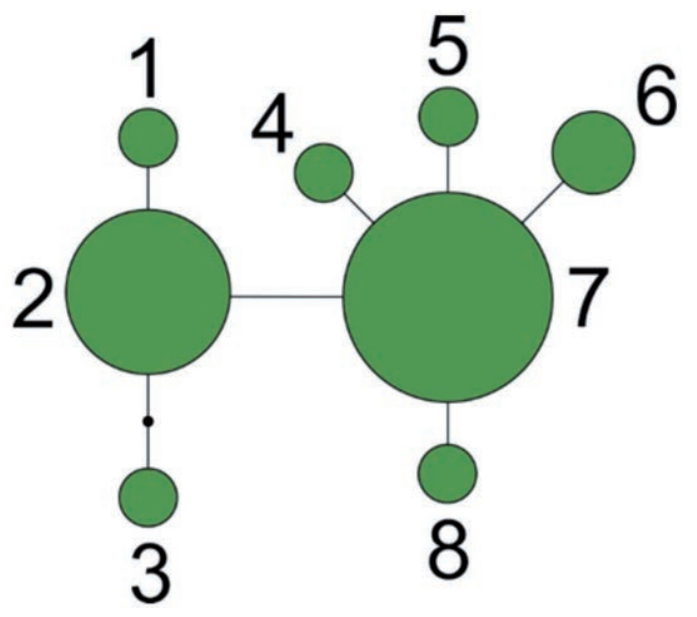

Fig. 4. Haplotype (TCS) network showing the relationships of Unio elongatulus specimens sequenced. Circle size is proportional to the observed haplotype frequencies and black points represent unobserved haplotypes and potential intermediates. 
$\mathrm{mg} \mathrm{L}{ }^{-1}$. Since the sedimentation rate is $\sim 0.22 \mathrm{~cm}^{\text {.year }}{ }^{-1}$ (Guilizzoni et al. 2001) the layer deposited between 1996 and 2001 (about $1 \mathrm{~cm}$ ) was probably not sufficient to isolate organisms from the toxic layers underneath. Furthermore, juvenile mussels, which have higher sensitivity to toxicants than adults (Wang et al., 2007a, 2007b) regularly burrow deeper than $5 \mathrm{~cm}$ and even as deep as $20 \mathrm{~cm}$ ( $<3$-cm size class; Schwalb and Pusch, 2007) becoming more exposed than adults to sediment bound contaminants (Yeager et al. 1994). We must therefore conclude that Unio elongatulus was able to recolonize, although the sediments were still contaminated by metals with concentrations largely exceeding the level known to have acute and chronic effects on most freshwater mussel species (Wang et al., 2007a, 2007b; US-EPA, 2007; Clearwater et al., 2014). Improvement of the habitat quality provided a suitable condition for survival, but for freshwater mussels not only water and sediment quality are important.

The recovery of (almost) the whole biocenosis is necessary to allow the survival of suitable and healthy hostfish populations. When the conditions of the lake started to improve, the biota, with the exception of fish, recovered but at different rates according their different resilience (Baudo, 2002). The recovery of the fish community was

Tab. 2. Water chemistry of Lake Orta (mean values at the spring overturn) (Rogora et al., 2016).

\begin{tabular}{|c|c|c|c|}
\hline Parameter & Unit & $\begin{array}{l}\text { Recovery } \\
\text { 1990-2000 }\end{array}$ & $\begin{array}{l}\text { Recent } \\
\text { 2001-14 }\end{array}$ \\
\hline $\mathrm{pH}$ & & 6.9 & 6.9 \\
\hline Cond. $20^{\circ} \mathrm{C}$ & $\mu \mathrm{S} \mathrm{cm}^{-1}$ & 108 & 102 \\
\hline Total alk. & meq $\mathrm{L}^{-1}$ & 0.11 & 0.26 \\
\hline $\mathrm{SO}_{4}^{--}$ & $\mathrm{mg} \mathrm{L}^{-1}$ & 30.9 & 24.2 \\
\hline $\mathrm{N}^{-\mathrm{NO}_{3}}{ }^{-}$ & $\mu \mathrm{g} \mathrm{N} \mathrm{L}^{-1}$ & 2758 & 1512 \\
\hline $\mathrm{Cl}^{-}$ & $\mathrm{mg} \mathrm{L}^{-1}$ & 2.5 & 3.6 \\
\hline $\mathrm{H}^{+}$ & $\mu$ eq $\mathrm{L}^{-1}$ & 0.1 & 0.1 \\
\hline $\mathrm{N}-\mathrm{NH}_{4}^{+}$ & $\mu \mathrm{g} \mathrm{N} \mathrm{L}^{-1}$ & 46 & 4 \\
\hline $\mathrm{Ca}^{++}$ & $\mathrm{mg} \mathrm{L}^{-1}$ & 13.2 & 12.9 \\
\hline $\mathrm{Mg}^{++}$ & $\mathrm{mg} \mathrm{L}^{-1}$ & 1.6 & 1.6 \\
\hline $\mathrm{Na}^{+}$ & $\mathrm{mg} \mathrm{L}^{-1}$ & 4.4 & 4.4 \\
\hline $\mathrm{K}^{+}$ & $\mathrm{mg} \mathrm{L}^{-1}$ & 1.0 & 1.0 \\
\hline $\mathrm{RSi}$ & $\mathrm{mg} \mathrm{Si} \mathrm{L} \mathrm{L}^{-1}$ & 3.6 & 2.5 \\
\hline $\mathrm{TN}$ & $\mathrm{mg} \mathrm{N} \mathrm{L}^{-1}$ & 3.0 & 1.6 \\
\hline $\mathrm{RP}$ & $\mu \mathrm{g} \mathrm{P} \mathrm{L}^{-1}$ & 1 & 2 \\
\hline $\mathrm{TP}$ & $\mu \mathrm{g} \mathrm{P} \mathrm{L}^{-1}$ & 5 & 5 \\
\hline $\mathrm{Cu}$ & $\mu \mathrm{g} \mathrm{L}^{-1}$ & 12 & 2 \\
\hline $\mathrm{Al}$ & $\mu \mathrm{g} \mathrm{L}^{-1}$ & 30 & 3 \\
\hline $\mathrm{Zn}$ & $\mu \mathrm{g} \mathrm{L}^{-1}$ & 30 & 14 \\
\hline $\mathrm{Fe}$ & $\mu \mathrm{g} \mathrm{L}^{-1}$ & 10 & 2 \\
\hline $\mathrm{Mn}$ & $\mu \mathrm{g} \mathrm{L}^{-1}$ & 80 & 2 \\
\hline $\mathrm{Cr}$ & $\mu \mathrm{g} \mathrm{L}^{-1}$ & 2 & 1 \\
\hline $\mathrm{Ni}$ & $\mu \mathrm{g} \mathrm{L}^{-1}$ & 14 & 8 \\
\hline
\end{tabular}

forecasted to be possible only after liming and through reintroduction (either from rivers or man-made) (Baudo, 2002). Fish restocking was the likely vector for mussels' reintroduction, because the isolation of the lake prevented access to dispersal or expansion of fish outside the lake.

\section{CONCLUSIONS}

Our data indicate that it took about 10 years after the reappearance of fish for Unio recovery, a delay which is not long, considering the difficulties created by the particular life history traits and requirements of these organisms. Indeed, their recovery was not yet expected and, for this reason, their presence has been overlooked until now. The most recent study of littoral benthos, examined exactly the same area that is now colonized, only two years before the beginning of colonization. But their presence escaped a subsequent (2003) search targeted specifically to freshwater mussels (Bodon, personal communication). Freshwater mussels are challenging to locate because they are often rare, spatially clustered, and difficult to detect (Downing and Downing, 1992; Strayer and Smith, 2003). The causes of imperfect detection in freshwater mussel surveys are varied (Smith et al., 2010) and only the adoption of appropriate sampling designs can reduce errors and improve survey success and reliability (Strayer and Smith, 2003). The recolonization of Lake Orta went unnoticed probably due to the limited extent of the colonized area, low density and, at least initially, the small size of individuals. In such cases the contribution of citizen science can be crucial to provide reports even of small populations in restricted, remote, and/or inaccessible areas. The casual discovery of mussels in Lake Orta was made possible thanks to an amateur video posted on YouTube and delivered us through Facebook: this highlights once more the potential roles of social networks for conservation and environmental issues (Cavalli et al., 2014).

Regardless of the recolonization mechanism, a greater priority should be placed on understanding the ecological processes that affect the success and failure of this important native mussel fauna in this ecosystem. Indeed, the population presently located at the south lake littoral over time may be a source of individuals to repopulate other near- or offshore, and perhaps the whole lake.

\section{AKNOWLEDGMENTS}

We are very grateful to the SCUBA divers team (SUB Novara Laghi) who greatly helped us during sampling, to Gianfranco Mazza who delivered the video and to Mario Savoini who realized it. A special thanks to Norman Yan for revising and commenting the manuscript draft. We are also very grateful to the anonymous reviewer for the constructive criticism that helped us to improve this manuscript. 


\section{REFERENCES}

Amyot J-P, Downing JA, 1997. Seasonal variation in vertical and horizontal movement of the freshwater bivalve Elliptio complanata (Mollusca: Unionidae). Freshwater Biol. 37:345-354.

Augspurger T, Keller AE, Black MC, Cope WG, Dwyer FJ, 2003. Water quality guidance for the protection of freshwater mussels (Unionidae) from ammonia exposure. Environ. Toxicol. Chem. 22:2569-2575.

Baldi E, 1949. [Il Lago d'Orta, suo declino biologico e condizioni attuali].[Article in Italian]. Mem. Ist. Ital. Idrobiol. 5:145-188.

Ballaré G, Bielli E, Fornara G, Masseroni P, 1992. [Qualità e utilizzo delle acque litorali del Lago d'Orta].[Article in Italian]. In: A. Calderoni and R. de Bernardi (eds.), Proc. Congress [Orta, un lago da salvare: le fasi del suo recupero]. Docum. Ist. Ital. Idrobiol. 38:83-94.

Barbero P, Beltrami M, Baudo R, Rossi D, 2001. Assessment of Lake Orta sediments phytotoxicity after the liming treatment. J. Limnol. 60:269-276.

Baudo R, 2002. Pollution and recovery of Lake Orta (Italy): resilience at work? Aquat. Ecosyst. Health 5:71-78.

Baudo R, Beltrami M, 2001. Chemical composition of Lake Orta sediments. J. Limnol. 60:213-236.

Baudo R, Occhipinti A, Nocentini AM, Sabolla M, 2001a. Benthos of Lake Orta in the year 1996. J. Limnol. 60:241-248.

Baudo R, Rossi D, Beltrami M, 2001b. In situ toxicity testing of Lake Orta sediments. J. Limnol. 60:277-284.

Beltrami M, Rossi D, Baudo R, 1999. Phytotoxicity assessment of Lake Orta sediments. Aquat. Ecosyst. Health 2:391-401.

Bielli E, Tesauro M, 2001. The littoral benthon community of Lake Orta after liming: a comparison between summer 1993 and summer 1998. J. Limnol. 60:237-239.

Bonacina C, 2001. Lake Orta: the undermining of an ecosystem. J. Limnol. 60:53-59.

Bonacina C, Bonomi G, Mosello R, 1986. Notes on the present recovery of Lake Orta: an acid, industrially polluted, deep lake in North Italy. Mem. Ist. ital. Idrobiol. 44:97-115.

Bonacina C, Bonomi G, Barbanti L, Mosello R, Ruggiu D, 1988a. Recovery of an industrially acidified, ammonia and heavy metal polluted lake (Lake Orta, N. Italy), due to the adoption of treatment plants. Verh. Intern. Ver. Limnol. 23:535-544.

Bonacina C, Bonomi G, Barbanti L, Mosello R, Ruggiu D, Tartari G, 1988b. Lake Orta (N. Italy): recovery after the adoption of restoration plans, p. 101-130. In: N.W. Schmidtke (ed.), Toxic contamination in Large Lakes. 2. Impact of toxic contaminants on fisheries management. Lewis Publishers.

Burton GA Jr, Baudo R, Beltrami M, Rowland C, 2001. Assessing sediment contamination using six toxicity assays. J. Limnol. 60:263-267.

Calderoni A, Mosello R, Quirci A, 1991. Chemical response of Lake Orta (Northern Italy) to liming. Arch. Hydrobiol. 122:421-439.

Calderoni A, Mosello R, Ruggiu D, 1992. Sixty years of limnology on Lago d'Orta: a case history of recovery from heavy pollution. In: P. Guilizzoni, G. Tartari and G. Giussani (eds.), Limnology in Italy. Mem. Ist. Ital. Idrobiol. 50:201-223.

Calderoni A, Tartari GA, 2000. Evolution of the water chemistry of Lake Orta after liming. J. Limnol. 60(s1):69-78.
Castagnolo L, 1977. [Ciclo biologico riproduttivo di Anodonta cygnea L. e Unio elongatulus Pfeiff. nel Po di Tolle].[Article in Italian]. Riv. Idrobiol. 16: 3-14.

Cavalli M, Baladrón AV, Isacch JP, Bó MS, Martínez G, 2014. Social networks and ornithology studies: an innovative method for rapidly accessing data on conspicuous bird species. Biodiv. Conserv. 23:2127-2134.

Clearwater SJ, Thompson KJ, Hickey CW, 2014. Acute toxicity of copper, zinc, and ammonia to larvae (glochidia) of a native freshwater mussel Echyridella menziesii in New Zealand. Arch. Environ. Contam. Toxicol. 66:213-226.

Clement M, Posada D, Crandall KA, 2000. TCS: a computer program to estimate gene genealogies. Mol. Ecol. 9:1657-1659.

Cope WG, Bringolf RB, Buchwalter DB, Newtown TJ, Ingersoll CG, Wang N, Augspurger T, Dwyer FJ, Barnhart MC, Neves RJ, Hammer E, 2008. Differential exposure, duration, and sensitivity of unionoidean bivalve life stages to environmental contaminants. J. North Am. Benthol. Soc. 27:451-462.

Corbella C, Tonolli V, Tonolli L, 1958. [I sedimenti del Lago d'Orta, testimoni di una disastrosa polluzione cuproammoniacale].[Article in Italian]. Mem. Ist. Ital. Idrobiol. 10:9-52.

Crail TD, Krebs RA, Zanatta DT, 2011. Unionid mussels from nearshore zones of Lake Erie. J. Great Lakes Res. 37:199-202.

Downing JA, Downing WL, 1992. Spatial aggregation, precision, and power in surveys of freshwater mussel populations. Can. J. Fish. Aquat. Sci. 49:985-991.

Downing JA, Rochon Y, Perusse M, 1993. Spatial aggregation, body size, and reproductive success in the freshwater mussel Elliptio complanata. J. N. Am. Benthol. Soc. 12:148-156.

Downing JA, Van Meter P, Woolnough DA, 2010. Suspects and evidence: a review of the causes of extirpation and decline in freshwater mussels. Anim. Biodivers. Conserv. 33:151-185.

Dunca E, Schone BR, Mutvei H, 2005. Freshwater bivalves tell of past climates: but how clearly do shells from polluted rivers speak. Palaeogeogr. Palaeocl. 228:43-57.

Froufe E, Sobral C, Teixeira, Sousa R, Varandas S, Aldridge DC, Lopes-Lima M, 2014. Genetic diversity of the pan-European freshwater mussel Anodonta anatina (Bivalvia: Unionoida) based on CO1: new phylogenetic insights and implications for conservation. Aquat. Conserv. 24:561-574.

Galbraith HS, Spooner DE, Vaughn CC, 2010. Synergistic effects of regional climate patterns and local water management on freshwater mussel communities. Biol. Conserv. 143:1175-1183..

Green RH, Singh SM, Bailey RC, 1985. Bivalve molluscs as response systems for modeling spatial and temporal environmental patterns. Sci. Tot. Env. 46:147-169.

Guilizzoni P, Lami A, Marchetto A, Appleby PG, Alvisi F, 2001. Fourteen years of palaeolimnological research of a past industrial polluted lake (L. Orta, Northern Italy): an overview. J. Limnol. 60:249-262.

Haag WR, 2012. North American freshwater mussels: natural history, ecology, and conservation. Cambridge University Press, Cambridge: 538 pp.

Haag WR, 2013. The role of fecundity and reproductive effort in defining life-history strategies of North American freshwater mussels. Biol. Rev. 88:745-766.

Haag WR, Commens-Carson AM, 2008. Testing the assumption of annual shell ring deposition in freshwater mussels. Can. J. Fish. Aquat. Sci. 65:493-508. 
Hastie L, Cosgrove P, Ellis N, Gaywood M, 2003. The threat of climate change to freshwater pearl mussel populations. Ambio 32:40-46.

Henderson PA, Seaby RM, 2006. Growth II. Pisces Conservation Ltd., Lymington. Available from: http:/www.piscesconservation.com/growthhelp/index.html?howtoreferenceth isprogram.htm

Henley WF, Neves RJ, 1999. Recovery status of freshwater mussels (Bivalvia: Unionidae) in the North Fork Holston River, Virginia. Am. Malacol. Bull. 15: 5-73.

Jones HA, Byrne M, 2010. The impact of catastrophic channel change on freshwater mussels in the Hunter river system, Australia: a conservation assessment. Aquat. Conserv. 20:18-30.

Jones HA, Byrne M, 2014. Changes in the distributions of freshwater mussels (Unionoida: Hyriidae) in coastal southeastern Australia and implications for their conservation status. Aquatic Conserv. 24:203-217.

Keller AE, Lydy M, Ruessler DS, 2006. Unionid mussel sensitivity to environmental contaminants, p.151-167. In: J.L. Farris and J.H. Van Hassel (eds.), Freshwater bivalve ecotoxicology. SETAC, Pensacola.

Lydeard C, Cowie RH, Ponder WF, Bogan AE, Bouchet P, Clark SA, Cummings KS, Frest TJ, Gargominy O, Herbert DG, Hershler R, Perez KE, Roth B, Seddon M, Strong EE, Thompson FG, 2004. The global decline of nonmarine mollusks. BioScience 54:321-330.

Matteson MR, Dexter RW, 1966. Changes in pelecypod populations in Salt Fork of Big Vermilion River, Illinois, 19181962. Nautilus 79:96-101.

McGoldrick DJ, Metcalfe-Smith JL, Arts MT, Schloesser DW, Newton TJ, Mackie GL, Monroe EM, Biberhofer J, Johnson K, 2009. Characteristics of a refuge for native freshwater mussels (Bivalvia: Unionidae) in Lake St. Clair. J. Great Lakes Res. 35:137-146.

McMahon RF, Bogan AE, 2001. Mollusca: Bivalvia, p. 331-429. In: J.H. Thorp and A.P. Covich (eds.), Ecology and classification of North American freshwater invertebrates. 2nd ed. Academic Press.

Monti R, 1930. [La graduale estinzione della vita del Lago d'Orta].[Article in Italian]. Rend. R. Ist. Lomb. Sci. Lett. 63:3-22.

Moretti GP, 1954a. [La distribuzione dei Tricotteri lungo il litorale del Lago d'Orta].[Article in Italian]. Mem. Ist. Ital. Idrobiol. 8:257-270.

Moretti GP, 1954b. [Il limnobio neritico dei Tricotteri a testimonianza dell'attuale situazione biologica del Lago d'Orta].[Article in Italian]. Boll. Soc. Eustachiana 47:59-117.

Mosello R, Bonacina C, Carollo A, Libera V, Tartari GA, 1986a. Acidification due to in-lake ammonia oxidation: an attempt to quantify the proton production in a highly polluted subalpine Italian lake (Lake Orta). Mem. Ist. Ital. Idrobiol. 44:47-71.

Mosello R, Baudo R, Tartari GA, 1986b. Metal concentrations in a highly acidic lake: L. Orta (Northern Italy). Mem. Ist. Ital. Idrobiol. 44:73-96.

Mosello R, Calderoni A, 1990. Pollution and recovery of Lake Orta (Northern Italy), p. 349-363. In: J.P. Giesy, R. Baudo and H. Muntau (eds.), Sediment chemistry and toxicity of in-place pollutants. Lewis Publishers.

Mosello R, Calderoni A, Tartari GA, 1989. pH related variations of trace metal concentrations in L. Orta. Sci. Total Environ. 87/88:255-268.

Naimo TJ, 1995. A review of the effects of heavy metals on freshwater mussels. Ecotoxicology 4:341-362.

Nardi PA, 1972. [Ricerche su un ecosistema ad Unio del preappennino pavese, II. Aspetti ecologici].[Article in Italian]. Boll. Pesca Piscic. Idrobiol 27:317-359.

Neves RJ, 1993. A state-of-the-unionids address, p. 1-10. In: K.S. Cummings, A.C. Buchanan and L.M. Koch (eds.), Conservation and management of freshwater mussels. Proc. Upper Mississippi River Conservation Comm. Symp., Rock Island, IL, USA.

Nobles T, Zhang Y, 2011. Biodiversity loss in freshwater mussels: importance, threats, and solutions, p. 137-162. In: O. Grillo (ed.), Biodiversity loss in a changing planet. InTech Available from: http://www.intechopen.com/books/biodiversity-loss-in-a-changing-planet/biodiversity-loss-infreshwater-mussels-importance-threats-and-solutions

Nocentini AM, Boggero A, De Margaritis G, Gianatti M, 2001. First phase of macroinvertebrate repopulation of-Lake Orta (Buccione Basin) after liming. J. Limnol. 60:110-126.

Økland J, Økland KA, 1986. The effects of acid deposition on benthic animals in lakes and streams. Experientia 42:471-486.

Oioli GF, 1969. [Ricerche sulla fauna litorale del Lago d'Orta].[PhD Thesis in Italian]. University of Milan.

Pini N, 1884. [Note malacologiche sulla fauna italiana].[Article in Italian]. Atti Soc. It. Sc. Nat. 27:79-87.

Piscia R, Yan N, Manca M, 2016. Mechanisms underlying recovery of zooplankton in Lake Orta after liming. J. Limnol. 75(s2):15-21.

Preston SJ, Harrison A, Lundy M, Roberts D, Beddoe N, Rogowski D, 2010. Square pegs in round holes - the implications of shell shape variation on the translocation of adult Margaritifera margaritifera (L.). Aquatic Conserv: Mar. Freshw. Ecosyst 20:568-573.

Ravera O, Beone GM, Cenci R, Lodigiani P, 2003. Metal concentrations in Unio pictorum mancus (Mollusca, Lamellibranchia) from 12 Northern Italian lakes in relation to their trophic level. J. Limnol., 62: 121-138.

Ravera O, Frediani A, Riccardi N, 2007. Seasonal variations in population dynamics and biomass of two Unio pictorum mancus (Mollusca, Unionidae) populations from two lakes of different trophic state. J. Limnol., 66 (1): 15-27.

Rogora M, Kamburska L, Mosello R, Tartari G, 2016. Lake Orta chemical status 25 years after liming: problems solved and emerging critical issues. J. Limnol. 75(s2):93-106.

Rossi D, Beltrami M, 1998. Sediment ecological risk assessment: In situ and laboratory toxicity testing of Lake Orta sediments. Chemosphere 37:2885-2894.

Sambrook J, Fritsch EF, Maniatis T, 1989. Molecular cloning: a laboratory manual. Cold Harbor Spring Press, New York 2028 pp:

Schwalb AN, Pusch MT, 2007. Horizontal and vertical movements of unionid mussels in a lowland river. J. N. Am. Benthol. Soc. 26:261-272.

Sietman BE, Whitney SD, Kelner DE, Blodgett KD, Dunn HL, 2001. Post-extirpation recovery of the freshwater mussel (Bivalvia: Unionidae) fauna in the upper Illinois River. J. Freshwat. Ecol. 16:273-281.

Smith DR, Gray BR, Newton TJ, Nichols D, 2010. Effect of im- 
perfect detectability on adaptive and conventional sampling: simulated sampling of freshwater mussels in the upper Mississippi River. Environ. Monit. Assess. 170:499-507.

Strayer DL, 2006. Challenges for freshwater invertebrate conservation. J. N. Am. Benthol. Soc. 25:271-287.

Strayer DL, 2008. Freshwater mussel ecology: a multifactor approach to distribution and abundance. University of California Press, Berkeley: 200 pp.

Strayer DL, Downing JA, Haag R, King TL, Layzer JB, Newton TJ, Nichols SJ, 2004. Changing perspectives on pearly mussels, North America's most imperiled animals. BioScience 54:429-439.

Strayer DL, Smith DR, 2003. A guide to sampling freshwater mussel populations. Monograph No. 8. American Fisheries Society: $103 \mathrm{pp}$.

Taskinen J, Berg P, Saarinen-Valta M, Välilä S, Mäenpää E, Myllynen K, Pakkala J, 2011. Effect of pH, iron and aluminum on survival of early life history stages of the endangered freshwater pearl mussel, Margaritifera margaritifera. Toxicol. Environ. Chem. 93:1764-1777.

Tesauro M, Bielli E, Cotta Ramusino M, Rossaro B, 1995. The littoral benthon of Lake Orta after liming. Mem. Ist. Ital. Idrobiol. 53:213-230.

US Environmental Protection Agency, 2007. Aquatic life ambient,freshwater quality criteria -copper, 2007 revision. EPA822-R-07-001. Office of Water, Washington, DC.

Volta P, Yan ND, Gunn JM, 2015. Past, present and future of the fish community of Lake Orta (Italy), one of the world's largest acidified lake. J. Limnol. 75(s2):131-141.

Walker JM, Bogan AE, Bonfiglio EA, Campbell DC, Christian AD, Curole JP, Harris JL, Wojtecki RJ, Hoeh WR, 2007. Primers for amplifying the hypervariable, male-transmitted COII-COI junction region in amblemine freshwater mussels
(Bivalvia: Unionoidea: Ambleminae). Mol. Ecol. Notes 7:489-491.

Walker JM, Curole JP, Wade DE, Chapman EG, Bogan AE, Watters GT, Hoeh WR, 2006. Taxonomic distribution and phylogenetic utility of gender-associated mitochondrial genomes in the Unionoida (Bivalvia). Malacologia 48:265-282.

Waller DL, Gutreuter S, Rach JJ, 1999. Behavioral responses to disturbance in freshwater mussels with implications for conservation and management. J. N. Am. Benthol. Soc. 18: 381-390.

Wang N, Ingersoll CG, Greer EI, Hardesty DK, Ivey CD, Kunz JL, Brumbaugh WG, Dwyer FJ, RobertsAD, Augspurger T, Kane CM, Neves RJ, 2007a. Chronic toxicity of copper and ammonia to juvenile freshwater mussels (Unionidae). Environ. Toxicol. Chem. 26:2048-2056.

Wang N, Ingersoll CG, Hardesty DK, Ivey CD, Kunz JL, Dwyer FJ, Roberts AD, Augspurger T, Kane CM, Neves RJ, Barnhart MC, 2007b. Acute toxicity of copper, ammonia, and chlorine to glochidia and juveniles of freshwater mussels (Unionidae). Environ. Toxicol. Chem. 26:2036-2047.

Watters GT, 2000. Freshwater mussels and water quality: A review of the effects of hydrologic and instream habitat alterations, p. 261-274. In: R.A. Tankersely, D.R. Warmolts, G.T. Watters, B.J. Armitage, P.D. Johnson and R.S. Butler (eds.) Freshwater mollusk Symposia Proceedings. Ohio Biological Survey, Columbus, OH, USA.

Watters GT, 2007. A brief look at freshwater mussel (Unionaceae) biology, p. 51-64. In: J.L. Farris and J.H. Van Hassel (eds.), Freshwater bivalve ecotoxicology. CRC Press.

Yeager MM, Cherry DS, Neves RJ, 1994. Feeding and burrowing behaviors of juvenile rainbow mussels, Villosa iris (Bivalvia:Unionidae). J. N. Am. Benthol. Soc. 13:217-222. 